\author{
Red. prof. dr. \\ Sonja Kump \\ lzr. prof. dr. \\ Sabina Jelenc \\ Krašovec \\ Doc. dr. Marko \\ Radovan \\ Filozofska fakulteta \\ Univerze $v$ Ljubljani
}

\section{UPORABA OSEBNEGA IZOBRAŽEVALNEGA NAČRTA V FORMALNEM IZOBRAŽEVANJU ODRASLIH - REZULTATI EVALVACIJSKE ŠTUDIJE}

\section{POVZETEK}

$V$ prispevku proučujemo vlogo osebnega izobraževalnega načrta (OIN) pri povečevanju uspešnosti odraslih v poklicnem in strokovnem izobraževanju v Sloveniji. Z anketnimi vprašalniki in kvalitativnimi intervjuji analiziramo mnenja organizatorjev in vodij izbranih ustanov, ki izvajajo izredno poklicno in strokovno izobraževanje odraslih ter odraslih udeležencev izobraževanja v teh programih. Zanima nas priprava in uresničevanje OIN, kdo sodeluje v tem procesu, kakšna je vloga OIN v procesu izobraževanja in s kakšnimi ovirami se v izobraževalnih organizacijah pri tem srečujejo. Ugotavljamo tudi stališča odraslih udeležencev poklicnega in strokovnega izobraževanja do priprave OIN in njegovega izvajanja; zanima nas njihovo doživljanje tega instrumenta kot motivacijskega dejavnika in kot dejavnika zmanjševanja ovir, ki jih doživljajo v procesu izobraževanja. Ugotovili smo, da se pri pripravi OIN pojavlja veliko težav, tako na strani organizatorjev in izvajalcev izobraževanja kot tudi na strani udeležencev. Vzroki za to so zlasti pomanjkanje kadra, ki bi poskrbelo za ustrezno pripravo in izvedbo OIN, pomanjkanje časa za pripravo OIN in drugih strukturnih možnosti, ki preprečujejo ustrezno načrtovanje izobraževalnega procesa v skladu z OIN. Tudi udeleženci večinoma ugotavljajo, da OIN v obliki, v kakršni se uporablja danes, večinama ni motivacijsko sredstvo in spodbuda za uspeřnejše izobraževanje in učenje.

Ključne besede: izobraževanje odraslih, osebni izobraževalni načrt, motivacija odraslih za izobraževanje, evalvacijska študija, formalno izobraževanje odraslih, načrtovanje izobraževanja

\section{MOTIVATION FOR ADULT EDUCATION - AN EXAMPLE OF AN EVALUATION STUDY OF A PERSONAL EDUCATION PLAN - ABSTRACT}

In this paper we examine the role of the personal education plan (PEP) in increasing the performance of adults in vocational and technical education in Slovenia. A survey questionnaire and the analysis of qualitative interviews were used in selected institutions, providing vocational and technical programmes for adult learners. We are interested in the preparation and realization of the PEP, who participates in the process, the role of the PEP in the educational process and what obstacles educational institutions are facing. We also examine the attitudes of the experts in educational institutions to preparation and implementation of the PEP. In addition, we are interested in their experience of this instrument as a participants' motivational factor and its influence on reducing the barriers they encounter in the process of education. We have found that in the preparation of PEP many problems appear for both the organisers and educators on the one hand and the learners on the other. The reasons are lack of human resources, particularly inthe preparation and execution of PEPs, lack of time for preparation of PEPs, and other, structural, circumstances preventing proper planning of the educational process in accordance with the PEP. The participants generally observe that, in the form used today, the PEPin most cases fails to be the motivational tool and incentive for better education and learning, which it was planned to become.

Keywords: adult education, personal education plan, motivation for adult education, evaluation study, formal adult education, educational planning

UDK: 374.7 


\section{UVOD}

Namen prispevka je predstaviti ugotovitve evalvacijske študije, ki smo jo na Filozofski fakulteti opravili v zvezi z vlogo osebnih izobraževalnih načrtov (OIN) pri povečevanju motivacije odraslih za izobraževanje, in sicer $\mathrm{z}$ vidika večje vztrajnosti, poglabljanja znanja in postavljanja višjih taksonomskih ciljev znanja, ter v zvezi z izkušnjami izobraževalcev odraslih pri pripravi teh načrtov za udeležence formalnega izobraževanja na izbranih izobraževalnih ustanovah. Teoretično ozadje priprave OIN za udeleženca izhaja iz prepričanja, da lahko to orodje pomembno povečuje motiviranost udeležencev za učenje, pripomore $\mathrm{k}$ zmanjševanju osipa $\mathrm{v}$ izobraževanju odraslih ter k uspešnejšemu pridobivanju znanja in spretnosti. Posledično lahko vpliva na razvoj poklicne kariere - pripomore $\mathrm{k}$ učinkovitejši izrabi znanj in spretnosti na poklicnem področju, za katerega se oseba izobražuje, in k vseživljenjskemu učenju tudi po zaključku formalnega izobraževanja.

V evalvacijski študiji, ki smo jo izvajali v letih 2011-2012, smo želeli ugotoviti, koliko se pri izvajanju strokovnega in poklicnega izobraževanja odraslih upoštevajo priporočila v zvezi z vpeljavo OIN v izobraževanje ter kakšna je vloga tega orodja pri motiviranju odraslih za izobraževanje in zagotavljanju njihovega uspešnejšega dokončanja izobraževanja. Pri tem smo proučevali tako mnenja organizatorjev/vodij izobraževanja na različnih ustanovah za izobraževanje odraslih kot tudi mnenja udeležencev izobraževanja.

\section{TEORETIČNA IZHODIŠČA ZA OBLIKOVANIE OSEBNEGA IZOBRAŽEVALNEGA NAČRTA}

Vključevanje OIN kot pripomočka pri učenju v našem šolskem sistemu ni novost. $\mathrm{Na}$ tak ali drugačen način so ga že $\mathrm{v}$ preteklosti uporabljali v rednem (»mladinskem«) izobraževanju kot tudi v izobraževanju odraslih, kjer so se razvijala podobna orodja $\mathrm{z}$ različnimi imeni (npr. »učna pogodba $v$ izobraževanju odraslih «, »zbirna mapa«, »osebni list « in podobno). Kar je novo, je formalno ozadje tega orodja, ki smo ga z različnimi zakoni in podzakonskimi akti formalizirali in postavili kot obveznost za izobraževalce.

S. Klemenčič (2004) opredeljuje OIN v širšem in ožjem smislu. V širšem pomenu gre pri OIN za dejavno odkrivanje poti, načinov in možnosti za izobraževanje, pri čemer mislimo na posameznikovo spoznavanje izobraževalnih možnostih ter seznanjanje $\mathrm{z}$ različnimi metodami in oblikami, s katerimi lahko doseže svoje izobraževalne cilje. V ožjem smislu pa opredeljuje OIN kot načrt izobraževanja ali učenja, ki je tako vsebinsko, ciljno, organizacijsko kot časovno prilagojen posamezniku (Klemenčič, 2004: 12).

Podobno navedeni ožji definiciji so OIN opredelili tudi Justinek in drugi (2010: 9), in sicer kot orodje, s katerim posameznik:

- načrtuje svojo pot izobraževanja do poklica ob pomoči mentorja,

- izbere vsebine, določi raven zahtevnosti in načrtuje čas za doseganje vmesnih ciljev in končnega cilja,

- $\quad$ evalvira vmesne dosežke in ugotavlja, kje na poti k cilju trenutno je,

- po potrebi spreminja oz. prilagaja svoj načrt glede na zastavljeni cilj,

- razvija odgovornost za svojo poklicno in osebnostno rast.

OIN je torej pripomoček, ki udeležencu izobraževanja omogoča prepoznavanje, načrtovanje in uresničevanje izobraževalnih ciljev, ki so skladni z njegovimi potrebami, interesi in zmožnostmi. 
Razvijanje podobnih orodij za pomoč posamezniku med učenjem oz. za usmerjanje ima $\mathrm{v}$ andragogiki dolgo tradicijo in njihove izvore lahko poiščemo pri več avtorjih. Najbolj neposredno pa izhaja iz koncepta »učnih pogodb « (angl. learning contracts), ki ga je v 80. letih razvijal Malcolm S. Knowles (1975, 1991). Pri tem je izhajal iz potrebe odraslih po samostojnosti pri učenju, upoštevanju izkušenj in drugih psiholoških potreb.

Pomen učnih pogodb v procesu učenja se je utemeljeval z različnimi teorijami, med drugim $\mathrm{z}$ raziskovanjem motivacijskih usmeritev (Houle, 1993), samostojnega učenja (angl. self-directed learning; Brockett in Hiemstra, 1991), poleg tega pa tudi z motivacijskimi teorijami, ki se ukvarjajo z vprašanji avtonomije in samouravnavanja učenja (Deci in Ryan, 1985; Zimmerman, 2002). V nadaljevanju si bomo na kratko pogledali njihov pomen za uspešno učenje udeleženca $\mathrm{v}$ izobraževanju in z njimi utemeljili prednost uporabe OIN v formalnem izobraževanju odraslih.

\section{SAMOSTOJNO UČENJE ODRASLIH}

Področje, ki se je v izobraževanju odraslih v zadnjih treh desetletjih najbolj razvijalo, je bilo samostojno učenje (v Sloveniji znano tudi pod imenom »usmerjeno samostojno učenje« in »samoizobraževanje «) - se pravi učenje, kjer odrasli sam vodi in usmerja svoje učenje. Čeprav se je v izobraževanju odraslih kot velika tema pojavilo šele v 70. in 80. letih, je ideja samostojnega učenja ( $\mathrm{tj}$. da odrasli sam nadzira potek svojega učenja) že zelo stara. Kulich (v Brockett in Hiemstra, 1991), recimo, v svojem zgodovinskem pregledu samostojnega učenja navaja primere zgodovinskih osebnosti, kot so Sokrat, Aleksander Veliki, Cezar in Descartes.
$\mathrm{V}$ andragogiki pa se je teorija samostojnega učenja utemeljila predvsem v delu Allena Tougha in raziskavah o učnih projektih odraslih (Tough, 1979). Tough se je pri svojem delu zelo opiral na raziskavo o motivacijskih usmeritvah odraslih, ki jo je opravil Houle (1993). Houle je intervjuval 22 odraslih in ugotovil tri temeljne učne usmeritve: usmeritev k ciljem, usmeritev $\mathrm{k}$ dejavnosti in usmeritev $\mathrm{k}$ učenju (Houle, 1993: 14-15).

Tougha so navdahnili predvsem tisti odrasli, ki so se uvrstili v skupino $» v$ učenje usmerjenih « udeležencev - to so bili torej tisti odrasli, pri katerih je učenje potekalo neprenehoma. Ko so končali eno učenje, so se lotili drugega. V svojem delu »Učni projekti odraslih« (Tough, 1979) je na vzorcu 66 odraslih raziskal pogostost in naravo tega »samonačrtovanega« učenja. Učni projekt je pri tem opredelil kot vrsto med seboj povezanih učnih epizod, ki trajajo skupaj najmanj sedem ur in so usmerjene $\mathrm{k}$ pridobivanju ali ohranjanju nekega znanja ali spretnosti (Tough, 1979: 7). Glavna ugotovitev raziskave je bila, da skoraj vsak človek v obdobju enega leta opravi vsaj en učni projekt in da so odrasli v vzorcu več kot dve tretjini vseh učnih dejavnosti načrtovali, izvajali in ocenjevali večinoma sami, pri preostalih pa jim je pomagal usposobljen strokovnjak. Številne ponovitve raziskave $\mathrm{z}$ različnimi vzorci odraslih so $\mathrm{v}$ veliki meri potrdile Toughove ugotovitve (gl. Brockett in Hiemstra, 1991).Veliko je bilo razprav o tem, kaj pravzaprav sestavlja samostojno učenje. Avtorji, kot sta Tough (1979) in Knowles (1975), so večinoma poudarjali pomen samostojnega učenja v okviru sistematičnega procesa oblikovanja takšne dejavnosti. Knowles (1975: 18) je recimo predlagal, da se izraz nanaša na proces, v katerem posameznik prevzame vodilno vlogo pri »prepoznavanju učnih potreb, oblikovanju učnih ciljev, prepoznavanju človeških in materialnih virov za učenje, izbiri in izvajanju 
ustreznih strategij učenja, učenju in ocenjevanju rezultatov«. Sčasoma so avtorji presegli te bolj deskriptivne opredelitve samostojnega učenja in začeli razpravljati o tem, kaj naj bi sploh bili cilji takega učenja (Brockett in Hiemstra, 1991), raziskovati osebnostne značilnosti odraslih, ki so pri samostojnem učenju uspešni (Candy, 1991), ali družbeni kontekst, $v$ katerem tako učenje poteka (Brookfield, 1985).

Brockett in Hiemstra (1991) sta razvila model usmerjenosti k osebni odgovornosti (angl. Personal Responsibility Orientation Model; PRO model). V PRO modelu se »samostojno učenje« uporablja kot krovni pojem, ki je sestavljen iz dveh povezanih razsežnosti: samostojnega učenja, ki poudarja elemente procesa učenja - večinoma tako, kot ga je opredelil Knowles -, in samostojnega učenja, ki se osredotoča na notranje značilnosti posameznika, kot »nagnjenost k prevzemanju odgovornosti « za učenje (Brockett in Hiemstra, 1991: 28-29). PRO model priznava tudi pomen družbenega konteksta, v katerem poteka učenje. Drugi poskus, s katerim naj bi povečali naše razumevanje samostojnega učenja, je mogoče najti v delu Candyja (1991), ki je k razumevanju samostojnega učenja pristopil s konstruktivističnega vidika. Candy razlikuje med samostojnostjo pri učenju kot »procesom ali metodo izobraževanja« in kot »ciljem ali izidom« (Candy, 1991: 19). Samostojnost pri učenju je razdelil na dve področji: nadzor učečega se, v katerem ta ohranja primarno odgovornost za učenje, in »avtodidaktičnost«, kjer učitelj ni udeležen in kjer lahko učenje poteka tudi priložnostno.

Razumevanje motivacijske vloge OIN ne bi bilo popolno, če ne bi omenili dveh psiholoških motivacijskih teorij, ki naše delovanje razumeta predvsem na podlagi avtonomije in nadzora: teorije samoodločanja (Deci in
Ryan, 2012) in teorije samoregulacijskega učenja (Zimmerman, 2002).

\section{TEORIJA SAMOODLOČANJA}

Teorijo samoodločanja (angl. self-determination theory) je razvil Edward L. Deci s sodelavci (Deci in Ryan, 1985, 2012). Po njihovem prepričanju izvira notranja motivacija iz dveh primarnih potreb posameznika: potrebe po kompetentnosti in potrebe po nadzoru nad svojim okoljem (Deci in Ryan, 1985). Pri tem avtorja poudarja-

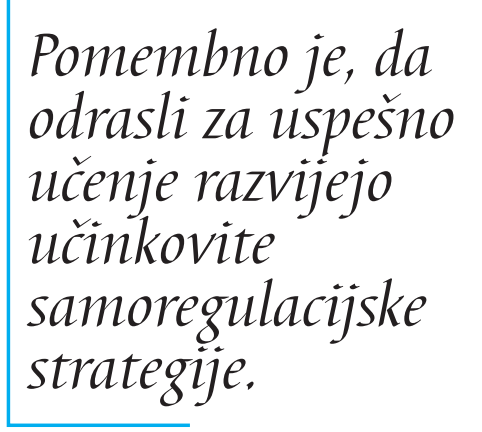
ta predvsem vpliv avtonomnega nasproti kontrolnemu kontekstu na posameznikovo notranjo motivacijo, ki jo zato definirata kot »človekovo potrebo po zaznavanju kompetentnosti in avtonomnosti lastnih dejanj v odnosu do okolja (prav tam: 27). Pravita, da avtonomija ne pomeni popolne neodvisnosti od zunanjega sveta, temveč je opredeljena $\mathrm{z}$ občutkom lastne volje, ki spremlja katerokoli posameznikovo dejanje ne glede na to, ali je avtonomno ali pa izvira iz zahtev v socialnem okolju. Posameznik je notranje motiviran takrat, ko deluje $\mathrm{v}$ skladu $\mathrm{s}$ svojimi odločitvami in izbirami. To pomeni, da bo posameznik notranje motiviran, ko bo imel občutek nadzora nad izbiro lastnega delovanja in možnost fleksibilnega uravnavanja dejavnosti. Primer: posameznik ima lahko prirojeno potrebo po učenju, manifestira pa jo z branjem knjig. Notranji motivaciji bo zadovoljeno, ko se posameznik odloči, katero knjigo bo prebral in kdaj bo to storil. Notranja motiviranost posameznika je zelo povezana tudi z občutkom kompetentnosti pri izvajanju nalog, dejavnosti ipd. Izzivi naj bi bili posamezniku dosegljivi. Če so prelahki, bo poiskal zahtevnejše; če so prezahtevni, pa se utegne njegov trud zmanjšati. 
Notranja motivacija se zmanjša, če posameznik nima možnosti uresničevati samoodločanja. Posameznik si želi izkusiti odgovornost za svoja dejanja in svobodo pri izbiranju.

Deci in sodelavci (1985) so opozorili na pomembno dimenzijo spodbujanja našega vedenja/motivacije, ki se lahko razteza od prisile do avtonomije posameznika. Oblike okrepitve, ki dopuščajo več avtonomije, so še posebno primerne za izobraževalne namene. Deci je prepričan, da bi morali v izobraževanju zmanjševati nadzor in spodbujati avtonomnost učečih se ter podpirati njihovo samostojnost pri odločanju. Povezava med notranjo motivacijo in vlogo OIN pri tem je iz tega primera več kot očitna.

\section{TEORIJA \\ SAMOREGULACIJSKEGA UČENIA}

Tudi notranje motivirani udeleženci imajo lahko težave pri upravljanju svojega učenja. S tega vidika je pomembna še druga dimenzija razumevanja motivacije: sposobnost, da razvijejo učinkovite samoregulacijske strategije za uspešno učenje. V najširšem pomenu besede samoregulacijo pri učenju opisujemo kot stopnjo metakognitivne, motivacijske in vedenjske dejavnosti v lastnem učnem procesu (Zimmerman, 2002). Za učeče se, ki dejavno uravnavajo svoje učenje, je značilno, da uporabljajo različne kognitivne in metakognitivne strategije, sistematično usmerjene k doseganju učnih ciljev. Uporabljajo tudi strategije, s katerimi uravnavajo druge vire učenja, kot so prilagoditev nekaterih vidikov fizičnega okolja in organiziranosti časa za učenje, tako da bi to postalo kar se da učinkovito. Pomembna sestavina samoregulacijskega učenja so še strategije, ki se nanašajo na uravnavanje učenja in učnega okolja. V to skupino strategij denimo sodijo organizacija časa, uravnavanje truda in ureditev prostora za učenje (Pintrich in Garcia, 1991).

Ugotovili so, da učeči se, ki svojega učenja ne uravnavajo zavestno, uporabljajo manj kognitivnih in metakognitivnih strategij, imajo negativno mnenje o lastni učinkovitosti in so bolj zunanje motivirani za učenje, pri doseganju ciljev pa so manj vztrajni (Zimmerman, 2002; Pintrich in Garcia, 1991). Raziskave, opravljene v zadnjih 20 letih, so pokazale pomembno povezanost med učnim uspehom in samouravnavanjem učenja pri osnovno-, srednje-, višje- in visokošolcih ter tudi pri odraslih udeležencih (Pintrich, 1989; Zimmerman in Martinez-Pons, 1990).

Model samoregulacijskega učenja, ki ga razvija Barry Zimmerman, temelji na Bandurovi socialnokognitivni teoriji (Zimmerman, 2002), v kateri je samouravnavanje opredeljeno kot zmožnost nadzora nad lastnim vedenjem, ki je podlaga posameznikove osebnosti, in predvideva tri korake:

- samoopazovanje - opazujemo sebe in svoje vedenje;

- $\quad$ vrednotenje - kar vidimo, primerjamo z določenim standardom ali merilom;

- $\quad$ samoodzivanje - če smo se po primerjavi z nekim standardom dobro izkazali, se nagradimo, kadar smo slabi, se grajamo (Bandura, 1997).

Po Zimmermanu (2002) je samoregulacijski proces po svoji naravi cikličen in izvira iz razmišljanja, občutkov in načrtovanega vedenja, ki so usmerjeni v doseganje postavljenih ciljev. Povedano drugače: informacije, ki jih dobimo pri učnih izkušnjah, so uporabne za prilagajanje ciljem, izbiranje strategij in prizadevanje. Ta definicija se razlikuje tudi od definicij, ki samouravnavanje učenja opisujejo z metakognitivnega zornega kota ter 
poudarjajo znanje in deduktivno mišljenje pri izbiri učne strategije. Čeprav ima metakogni-

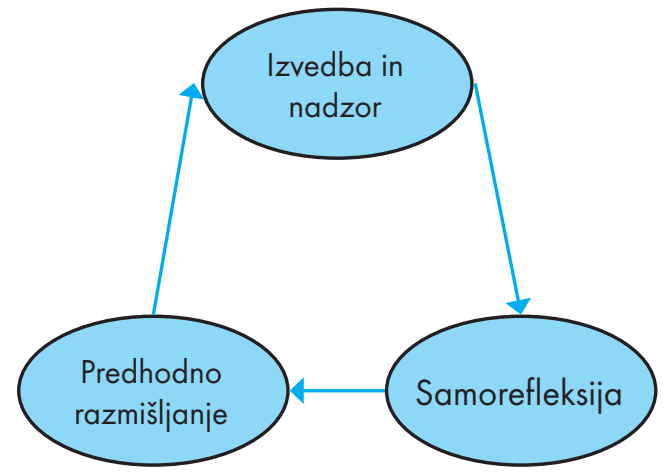

Slika 1. Socialnokognitivni model samoregulacijskega učenja (Vir: Zimmerman, 2002: 67)

cija pomembno vlogo, je samouravnavanje odvisno predvsem od prepričanj o sebi in od posameznikovih čustvenih odzivov. Krožni model samoregulativnega učenja je sestavljen iz treh faz, v katerih oseba načrtuje, izvaja in vrednoti svoje učenje (Slika 1).

Faza predhodnega razmišljanja zadeva procese in prepričanja, ki so časovno pred učenjem in so nekakšna priprava na učenje. Druga faza, faza izpeljave in nadzora, vključuje procese, ki potekajo med učenjem in pomagajo učencem $\mathrm{k}$ boljši osredotočenosti na nalogo in njeno optimalno izvedbo, na primer: strategije pri nalogi pomagajo pri učenju z omejitvijo naloge na njene bistvene sestavine in bolj smiselno organizacijo. Zadnja faza, tako imenovana faza samorefleksije, vključuje procese po učenju, kot sta samovrednotenje in ocenjevanje dosežkov (Zimmerman, 2002).

Teorija samoregulacijskega učenja poudarja, da mora biti posameznik ne samo motiviran, da bo uspešno zaključil svoje učenje, ampak tudi to, da mora poznati načine in strategije, kako bo dosegel svoje cilje.

\section{OSEBNI IZOBRAŽEVALNI NAČRT KOT UČNA METODA ALI UČNI PRIPOMOČEK}

Uporaba OIN in podobnih orodij je v izobraževanju odraslih različno opredeljena. Nekateri avtorji ta pripomoček opredeljujejo kot učno metodo (O`Donnell in Cafferella, 1991: 133) in se pri tem osredotočajo predvsem na njegovo uporabo $\mathrm{v}$ formalnem izobraževanju odraslih. Učna pogodba je v tem smislu razumljena predvsem kot sredstvo individualizacije procesa izobraževanja. Uporaba termina »pogodba« daje dogovoru med udeležencem izobraževanja in učiteljem bolj obvezujoč prizvok - ta zaveza velja za oba, tako za udeleženca kot učitelja.

Knowles (1975) je učne pogodbe razvijal kot pripomoček za spodbujanje in razvoj samostojnega učenja ter pri tem predvidel pet korakov:

1. določanje učnih potreb,

2. določanje učnih virov in strategij,

3. ugotavljanje dosežkov učenja,

4. evalvacija rezultatov učenja (Knowles, 1975: 26).

Pomembna značilnost priprave učne pogodbe je v tem, da je v celotnem procesu udeleženec dejavno vključen. Ta vključenost je bolj samoumevna v neformalnem izobraževanju, možna pa je tudi v formalnem - kljub vnaprejšnji določenosti izobraževalnih ciljev. To pomeni, da so vsebine in cilji največkrat nespremenljivi, prilagoditve pa se lahko zgodijo pri tem, kako bo posameznik te cilje dosegel.

Podobno v zvezi z odločitvijo o uporabi OIN razmišlja tudi T. Možina (2004). Po njenem mnenju bi se morali pred odločitvijo za ustrezno obliko OIN vprašati glede vrste izobraževanja (ali je bolj ali manj strukturirano, daljše ali krajše itd.) in glede značilnosti udeležencev izobraževanja (Možina, 2004: 56). 
O'Donnell in Cafferella (1991) naštevata štiri glavne prednosti učenja s pomočjo učnih pogodb:

1. Fleksibilnost pristopa omogoča mnogotere učne izkušnje.

2. Učeči se nadzira proces učenja.

3. Učenje s pogodbo omogoča razvoj spretnosti načrtovanja lastnega učenja.

4. Udeležencem je tako učenje bolj všeč (O`Donnell in Cafferella, 1991: 139).

Anderson, Boud in Sampson (1996) pa med prednosti oz. razloge, zaradi katerih je uporaba učnih pogodb smiselna, uvrščajo relevantnost učenja (tako učenje je bolj prilagojeno potrebam učečega se in njegovim ciljem), avtonomnost (učne pogodbe dajejo učečemu se odgovornost za doseganje postavljenih ciljev in dogovorjenega učenja), strukturo (učna pogodba postavlja formalni okvir učenja ter mu daje jasne cilje in usmeritve) in enakost (prilagajanje poteka učenja specifičnim potrebam in značilnostim učečega se povečuje zavedanje o individualnih ali kulturnih razlikah med udeleženci izobraževanja in daje ustanovam orodje, da te razlike prepoznajo).

\section{ZAKONSKE PODLAGE ZA OSEBNI IZOBRAŽEVALNI NAČRT}

Strokovna in zakonska podlaga za OIN so Navodila o prilagajanju izrednega poklicnega in strokovnega izobraževanja, ki opredeljujejo vsebino in način priprave OIN, pripravljena pa so bila na podlagi 64. člena Zakona o poklicnem in strokovnem izobraževanju (2006). OIN je v izhodišču namenjen načrtovanju posameznikove izobraževalne poti. OIN naj se pripravi na pobudo posameznika ob pomoči svetovalca oz. organizatorja izobraževanja odraslih. Začne se z uvodnim pogovorom, kjer se na podlagi posamezniko- vega predhodno pridobljenega znanja pripravijo ustrezna dokumentacija ter vsebinski in izvedbeni načrt nadaljnjega izobraževanja. Izvajalec izobraževanja predstavi udeležencu namen in vsebino izobraževanja, posameznik pa ima možnost OIN dopolniti z lastnimi predlogi. Skupaj torej pripravita načrt izobraževanja (cilje, vsebine, časovni načrt idr.), kjer se upoštevajo želje, potrebe, sposobnosti in zmožnosti posameznika. Izvajalec izobraževanja in udeleženec se zavežeta in podpišeta pogodbo (prav tam: 13. člen).

V Navodilih o prilagajanju izrednega poklicnega in strokovnega izobraževanja, ki opredeljujejo vsebino in način priprave OIN (prav tam: 14. člen), je določeno, naj se za preverjanje uresničevanja OIN uporablja evalvacijski pogovor med udeležencem in izvajalci izobraževanja, in sicer vsaj enkrat na leto. Po potrebi se OIN lahko spremeni.

Za OIN je določena vsebina za skupinski (prav tam: 12. do 14. člen) in individualni organizacijski model (prav tam: 15. do 18. člen), pri čemer se predpisuje, katere podatke (prav tam: 16. člen) in katere postopke za prilagoditev (prav tam: 15. člen) naj OIN vsebuje. Prepoznavnost pomena OIN je razvidna tudi iz Navodil o prilagajanju izrednega poklicnega in strokovnega izobraževanja (2008). V 13. členu teh navodil je zapisano, da je OIN dokument, v katerem izobraževalna organizacija poleg »prilagoditev iz izvedbenega načrta za učno skupino opredeli še morebitne posebnosti pri načrtovanju izobraževalne poti za posameznika, ki se razlikujejo od sprejetega izvedbenega načrta za učno skupino«. Te prilagoditve zajemajo določitev vsebin, časovni potek izobraževanja, priznavanje predhodno pridobljenega znanja in načine preverjanja znanja. OIN stopi v veljavo, ko ga podpišeta udeleženec in izvajalec izobraževanja. 


\section{METODOLOGIJA}

Podatki so bili zbrani v okviru evalvacijske raziskave, ${ }^{1}$ katere namen je bil ugotoviti, koliko se pri izvajanju strokovnega in poklicnega izobraževanja odraslih upoštevajo Navodila o prilagajanju izrednega poklicnega in strokovnega izobraževanja, opredeljena $\mathrm{V}$ Zakonu o poklicnem in strokovnem izobraževanju (2006), ter kakšna je vloga OIN pri motiviranju odraslih za izobraževanje in zagotavljanju njihovega uspešnejšega dokončanja študija. Pri tem smo proučevali tako mnenja organizatorjev oz. vodij izobraževanja na različnih ustanovah za izobraževanje odraslih kot tudi mnenja udeležencev izobraževanja.

Raziskava je potekala kot kombinacija kvantitativnega in kvalitativnega pristopa. S prvim smo želeli ugotoviti mnenja strokovnjakov na izobraževalnih ustanovah o OIN in težave, s katerimi se srečujejo pri njegovem uresničevanju. Vlogo OIN pa smo preverili tudi $\mathrm{z}$ intervjuvanjem udeležencev ter $\mathrm{s}$ tem bolj poglobljeno proučili njegov motivacijski pomen pri učenju in večji angažiranosti v času izobraževanja. Na izbranih ustanovah smo stališča organizatorjev izobraževanja odraslih do omenjenih vprašanj ugotavljali s spletno anketo, na vsaki ustanovi pa smo intervjuvali tudi po dva do tri udeležence strokovnega ali poklicnega izobraževanja odraslih.

V okviru kvantitativnega dela proučevanja smo v vzorec evalvacijske raziskave vključili vodje oz. organizatorje izobraževanja na izbranih ljudskih visokih šolah in oddelkih za odrasle na srednjih poklicnih in strokovnih šolah. Anketni vprašalnik je bil poslan na 22 izobraževalnih ustanov (devet ljudskih univerz in 13 enot za izobraževanje odraslih na srednji šoli) po vnaprejšnjem dogovoru. Vrnjenih je bilo 17 vprašalnikov, devet $\mathrm{z}$ ljudskih univerz in sedem iz enot za izobraževanje odraslih na srednjih šolah (ena ustanova ni odgovorila na vprašanje o vrsti ustanove in je ostala neopredeljena).

Za namene kvalitativnega dela raziskave smo na vsaki od ustanov, kjer smo najprej s spletno anketo ugotavljali stališča organizatorjev izobraževanja odraslih, intervjuvali tudi dva do tri udeležence strokovnega ali poklicnega izobraževanja odraslih. Za namene kvalitativnega raziskovanja smo izvedli 62 intervjujev z odraslimi udeleženci programov strokovnega ali poklicnega izobraževanja na ljudskih univerzah in srednjih šolah. Med intervjuvanci je bilo 30 moških in 32 žensk, od tega jih je 49 ( 80 odstotkov) sodelovalo v organiziranem izobraževanju, 14 (20 odstotkov) pa $\mathrm{v}$ individualiziranem organizacijskem modelu (samostojno, opravljajo le izpite).

Intervjuvanje so izvajali študenti 4. letnika andragogike, ki smo jih za to posebej usposobili. Zanimalo nas je sovplivanje dejavnikov, s katerimi bi osvetlili razumevanje pomena OIN in njegove motivacijske funkcije za udeležence izobraževanja. Pri tem smo se zavedali specifičnosti takšnega kvalitativnega raziskovanja, ki omogoča sklepanje na podlagi analize primerov, podprte z ustreznimi teoretskimi predpostavkami. To raziskovanje omogoča postavitev $\gg$ sorazmerno verjetne teorije « (Mesec, 1998: 48), nikakor pa ne sklepov, ki bi temeljili na preverljivih dejstvih in zakonitostih. $\mathrm{Z}$ analitično indukcijo smo poskušali sklepati, kakšna je po mnenju udeležencev izobraževanja vloga OIN v spletu vseh ukrepov za motiviranje in pomoč pri učenju. Naše raziskovanje je sledilo izhodiščem, ki sta jih v svojem pojasnjevanju utemeljene teori$\mathrm{je}^{2}$ (angl. Grounded Theory) zagovarjala Strauss in Corbin (1990), prej pa tudi Glaser in Strauss (1967). Gre za induktivno sklepanje iz niza podatkov, ki pa ne omogoča dedukcije. Upoštevali smo tudi sam proces raziskovanja kot pomemben del raziskave in analitično opazovali vse spremembe dejavnosti, ki so se pojavljale v času. 


\section{UGOTOVITVE EVALVACIJSKE ŠTUDIJE}

Velika večina anketiranih organizatorjev izobraževanja je seznanjena $\mathrm{z}$ določbami Zakona o poklicnem in strokovnem izobraževanju. Navodila o prilagajanju izrednega poklicnega in strokovnega izobraževanja, ki opredeljujejo vsebino in način priprave OIN, organizatorji

Tabela 1: Ali v osebni izobraževalni načrt vključite: izobraževanja odraslih $\mathrm{v}$ večjem deležu upoštevajo. Tisti, ki navodila upoštevajo le delno, navajajo težave s pomanjkanjem časa in kadra.

Analiza odgovorov organizatorjev izobraževanja je pokazala, da OIN za celotno šolsko letopripravijo v vseh ustanovah, vključenih v raziskavo. Odgovori intervjuvanih udeležencev na enako vprašanje se razlikujejo; tretjina jih je izjavila, da nimajo OIN, nekateri med njimi so med intervjujem prvič slišali zanj. OIN na

\begin{tabular}{|c|c|c|c|c|c|c|c|}
\hline & Nikoli & Redko & Občasno & Pogosto & Vedno & Skupaj & Povprečje \\
\hline $\begin{array}{l}\text { - podatke o formalnih } \\
\text { in neformalnih delovnih } \\
\text { in drugih izkušnjah (kva- } \\
\text { lifikacijah) kandidata? }\end{array}$ & $1(5,9 \%)$ & $1(5,9 \%)$ & $0(0,0 \%)$ & 5 & 10 & $\begin{array}{c}17(100,0 \\
\%)\end{array}$ & 4,29 \\
\hline $\begin{array}{l}\text { - podatke o zaključe- } \\
\text { nem predhodnem for- } \\
\text { malnem izobraževanju, } \\
\text { vkliučno z morebitnimi } \\
\text { posebnostmi? }\end{array}$ & $1(5,9 \%)$ & $0(0,0 \%)$ & $0(0,0 \%)$ & $1(5,9 \%)$ & $15(88,2 \%)$ & $\begin{array}{c}17(100,0 \\
\%)\end{array}$ & 4,71 \\
\hline $\begin{array}{l}\text { - podatke o znanju, pri- } \\
\text { doblienem v neformal- } \\
\text { nem izobraževanju? }\end{array}$ & $1(5,9 \%)$ & $2(11,8 \%)$ & $4(23,5 \%)$ & $3(17,6 \%)$ & $7(41,2 \%)$ & $17(100,0 \%)$ & 3,76 \\
\hline $\begin{array}{l}\text { - podatke o predvidenem } \\
\text { vsebinskem in časovnem } \\
\text { poteku izobraževanja? }\end{array}$ & $0(0,0 \%)$ & $0(0,0 \%)$ & $1(5,9 \%)$ & $3(17,6 \%)$ & $13(76,5 \%)$ & $17(100,0 \%)$ & 4,71 \\
\hline $\begin{array}{l}\text {-podatke o načinih in ro- } \\
\text { kih preverjanja znanja? }\end{array}$ & $0(0,0 \%)$ & $1(5,9 \%)$ & $1(5,9 \%)$ & $5(29,4 \%)$ & $10(58,8 \%)$ & $17(100,0 \%)$ & 4,41 \\
\hline $\begin{array}{l}\text { - podatke o poteku in } \\
\text { časovnih rokih za spre- } \\
\text { mljanje uresničevanja } \\
\text { osebnega izobraževal- } \\
\text { nega načrta? }\end{array}$ & $0(0,0 \%)$ & $0(0,0 \%)$ & $5(29,4 \%)$ & $6(35,3 \%)$ & $6(35,3 \%)$ & $17(100,0 \%)$ & 4,06 \\
\hline $\begin{array}{l}\text { - predloge za potek } \\
\text { konzultacij? }\end{array}$ & $1(5,9 \%)$ & $2(11,8 \%)$ & $3(17,6 \%)$ & $4(23,5 \%)$ & $7(41,2 \%)$ & $17(100,0 \%)$ & 3,82 \\
\hline $\begin{array}{l}\text { - opredelitev, kako se } \\
\text { bo udeležencu poma- } \\
\text { galo pri dostopu do } \\
\text { ustreznih učnih virov? }\end{array}$ & $2(11,8 \%)$ & $0(0,0 \%)$ & $3(17,6 \%)$ & $7(41,2 \%)$ & $5(29,4 \%)$ & $17(100,0 \%)$ & 3,76 \\
\hline
\end{tabular}


anketiranih izobraževalnih ustanovah večinoma pripravljajo skupaj z udeležencem, vendar obstajajo razlike glede na način in obseg sodelovanja. Nekateri OIN pripravljajo individualno, z vsakim udeležencem posebej, drugi pa kombinirajo skupinsko in individualno pripravo. V manjši meri organizatorji izobraževanja odraslih sami pripravijo OIN za udeleženca in ga z njim le seznanijo. Po potrebi pa ga med šolskim letom ustrezno prilagajajo.

Iz odgovorov anketiranih organizatorjev izobraževanja, ki so predstavljeni v Tabeli 1 , je razvidno, da v OIN najpogosteje vključijo podatke o zaključenem predhodnem formalnem izobraževanju, vključno z morebitnimi posebnostmi, podatke o predvidenem vsebinskem in časovnem poteku izobraževanja, podatke o načinih in rokih preverjanja znanja, podatke o formalnih in neformalnih delovnih in drugih izkušnjah (kvalifikacijah) kandidata ter podatke o poteku in časovnih rokih za spremljanje uresničevanja OIN, preostali podatki pa se $\mathrm{v}$ povprečju uporabljajo v manjši meri.

Nekateri organizatorji v OIN vključijo še celoten načrt obveznosti in posebej letni načrt obveznosti, delovni status, delovne izkušnje, pričakovanja o izobraževanju, ovire, spodbude in priložnosti za izobraževanje, cilje, motivacijo, opombe organizatorja. Do zagotavljanja obveznih individualnih ali skupinskih konzultacij (pet ur) se večina ni opredelila, kot tudi ne do pomoči pri dostopanju do ustreznih učnih virov. Večina intervjuvanih udeležencev, ki imajo svoj OIN, meni, da njegovo vsebino pozna, toda njihovi odgovori na konkretnejša vprašanja o vsebini so dokaj nejasni.

Na splošno izvajalci izobraževanja odraslih navodila v večji meri upoštevajo pri individualizirani obliki izobraževalnega modela, manj pa pri skupinskih oblikah, kjer je veliko število udeležencev. Iz odgovorov organizatorjev izobraževanja pa lahko razberemo, da mnogi OIN pripravljajo predvsem zato, da zadostijo Zakonu o poklicnem in strokovnem izobraževanju, torej kot formalnost, ki jo je treba izpolniti in ki zahteva dodatno administrativno delo, sicer pa se nekateri med njimi sploh ne zavedajo pravega smisla in namena OIN.

Večina anketiranih organizatorjev izobraževanja pridobiva mnenje udeležencev o ustreznosti izvedbe izobraževanja glede na njihove OIN vsaj enkrat, nekateri tudi dvakrat na leto, so pa tudi takšni, ki tega ne počnejo. Navodila o prilagajanju izrednega poklicnega in strokovnega izobraževanja sicer določajo, da se evalvacijski pogovor opravi vsaj enkrat na leto, kar pomeni, da organizatorji izobraževanja $\mathrm{v}$ tem pogledu $\mathrm{v}$ veliki meri upoštevajo zakonska določila.

Po izjavah nekaj več kot polovice organizatorjev izobraževanja $\mathrm{v}$ njihovih organizacijah program izobraževanja prilagajajo potrebam posameznika, vendar je še vedno velik delež takih, ki to upoštevajo v manjši meri ali pa sploh ne. Večina udeležencev pa po drugi strani trdi, da teh prilagoditev ni, oziroma da ne vedo, ali jih na izobraževalni ustanovi izvajajo.

Organizatorji izobraževanja opozarjajo na problem prilagajanja pri udeležencih izobraževanja, ki so se vpisali že pred časom. Ker se v vmesnem času izobraževalni program spreminja, je za takšne udeležence treba pripraviti nov OIN. Sicer pa imajo udeleženci izobraževanja možnost prilagojenega opravljanja obveznosti, kar pomeni, da nekateri izpite opravijo hitreje, kot je predvideno v njihovem OIN, tistim, za katere je tempo prehiter, pa dovoljujejo počasnejše opravljanje obveznosti, kot je bilo prvotno načrtovano.

Analiza odgovorov organizatorjev izobraževanja je pokazala, da se uresničevanje 
sprejetega izvedbenega načrta za učno skupino in uresničevanje OIN v večji meri spremljata skozi evalvacijske pogovore $\mathrm{z}$ udeleženci in učitelji. Če se pri evalvacijskem pogovoru pokažejo težave pri uresničevanju načrta, se ustrezne spremembe OIN pripravijo med letom. Koliko oziroma ali se izvedbeni načrt za učno skupino prilagaja med letom (npr. dodatne aktivnosti v smislu pomoči), iz analize vprašalnikov ni razvidno. Primerjava odgovorov udeležencev izobraževanja pokaže, da večina ne ve veliko o prilagajanju OIN,

Tabela 2: V kakšne namene uporabljate osebni izobraževalni načrt? medtem ko vsi, ki imajo svoj OIN, izjavljajo, da se ta načrt med njihovim izobraževanjem ni spreminjal.

Rezultati analize anketnega vprašalnika so pokazali, da učitelji $\mathrm{v}$ uvodnem pogovoru nikoli ne sodelujejo. Informiranost učiteljev o vlogi in pomenu OIN je večinoma skromna. To pa pomeni, da učitelj težko pripomore $\mathrm{k}$ uresničevanju OIN, če ga sploh ne pozna ter ni seznanjen s posebnostmi in potrebami udeležencev. Približno polovica organizatorjev navaja, da se v okviru evalvacijskega pogovora enkrat ali dvakrat na leto $\mathrm{z}$ učitelji posvetujejo o ustreznosti OIN za posameznega

\begin{tabular}{|c|c|c|c|c|c|c|c|}
\hline & $\begin{array}{l}\text { Sploh se ne } \\
\text { strinjam }\end{array}$ & $\begin{array}{l}\text { Se ne } \\
\text { strinjam }\end{array}$ & Niti niti & Se strinjam & $\begin{array}{l}\text { Povsem se } \\
\text { strinjam }\end{array}$ & Skupaj & Povprečje \\
\hline $\begin{array}{l}\text { Kot motivacijsko } \\
\text { sredstvo }\end{array}$ & $1(6,3 \%)$ & $1(6,3 \%)$ & $5(31,3 \%)$ & $3(18,8 \%)$ & $6(37,5 \%)$ & $16(100,0 \%)$ & 3,75 \\
\hline $\begin{array}{l}\text { Kot sredstvo za } \\
\text { organizacijo učnega } \\
\text { procesa udeležencev }\end{array}$ & $0(0,0 \%)$ & $0(0,0 \%)$ & $2(12,5 \%)$ & $9(56,3 \%)$ & $5(31,3 \%)$ & $16(100,0 \%)$ & 4,19 \\
\hline $\begin{array}{l}\text { Kot sredstvo za lažje } \\
\text { načrtovanje izobraže- } \\
\text { valne poti udeležencev }\end{array}$ & $0(0,0 \%)$ & $1(6,3 \%)$ & $0(0,0 \%)$ & $8(50,0 \%)$ & $7(43,8 \%)$ & $16(100,0 \%)$ & 4,31 \\
\hline $\begin{array}{l}\text { Kot sredstvo za vre- } \\
\text { dnotenje formalnih in } \\
\text { neformalnih delovnih } \\
\text { izkušenj }\end{array}$ & $1(6,7 \%)$ & $1(6,7 \%)$ & $2(13,3 \%)$ & $9(60,0 \%)$ & $2(13,3 \%)$ & $15(100,0 \%)$ & 3,67 \\
\hline $\begin{array}{l}\text { Kot sredstvo za pri- } \\
\text { znavanje predhodno } \\
\text { pridoblienih znanj in } \\
\text { spretnosti }\end{array}$ & $0(0,0 \%)$ & $4(25,0 \%)$ & $0(0,0 \%)$ & $9(56,3 \%)$ & $3(18,8 \%)$ & $16(100,0 \%)$ & 3,69 \\
\hline $\begin{array}{l}\text { Kot sredstvo za } \\
\text { izboljšanje kakovosti } \\
\text { programa izobraže- } \\
\text { vanja }\end{array}$ & $0(0,0 \%)$ & $3(18,8 \%)$ & $5(31,3 \%)$ & $7(43,8 \%)$ & $1(6,3 \%)$ & $16(100,0 \%)$ & 3,38 \\
\hline $\begin{array}{l}\text { Kot sredstvo za } \\
\text { uspešnejše načrtova- } \\
\text { nje in večjo kakovost } \\
\text { procesa poučevanja }\end{array}$ & $0(0,0 \%)$ & $3(18,8 \%)$ & $4(25,0 \%)$ & $7(43,8 \%)$ & $2(12,5 \%)$ & $16(100,0 \%)$ & 3,50 \\
\hline
\end{tabular}


udeleženca izobraževanja. To pomeni, da le polovica učiteljev upošteva Navodila o prilagajanju izrednega poklicnega in strokovnega izobraževanja, ki opredeljujejo vsebino in način priprave OIN. Ta podatek ni spodbuden, saj so učitelji nosilci izobraževalnih vsebin po predmetih in so v neposrednem stiku z udeleženci. Ali je vzrok v pomanjkanju kadra ali pa so problemi drugje, je težko odgovoriti. Vsekakor bi bilo treba na tem področju storiti več, saj strokovnjaki opozarjajo na pomembno vlogo učitelja, ki naj bi sodeloval pri pripravi OIN (za predmet, katerega nosilec je) ter pomagal odraslemu pri spremljanju njegovega izobraževanja glede na oblikovani OIN in pri končnem vrednotenju, kaj je pri posameznem predmetu dosegel. Ne nazadnje pa je OIN za učitelja lahko tudi pripomoček za lažje načrtovanje dela $v$ skupinah in vrednotenje lastnega dela. Na vprašanje, ali se z učitelji posvetujejo in pogovarjajo o uresničevanju svojega OIN, so vsi odrasli udeleženci poklicnega in strokovnega izobraževanja odgovorili nikalno. Po mnenju mnogih intervjuvancev je večina učiteljev v učnem procesu sicer pripravljena pomagati, če se pojavijo težave, vendar pa ta pomoč nikoli ni povezana $\mathrm{z}$ doseganjem ciljev in uresničevanjem zahtev, zapisanih v OIN, temveč je vezana na pomoč pri učnih urah in v izobraževalnem procesu.

Organizatorji izobraževanja OIN v veliki meri vidijo kot motivacijsko sredstvo za udeležence izobraževanja (Tabela 2).

Kakovostno pripravljen OIN lahko udeležencu služi kot oporna točka, lahko vidi cilj in kako se mu približuje. Pomembno pa je tudi, da OIN udeleženec sestavi skupaj z organizatorjem, saj se le tako lahko upoštevajo njegove individualne potrebe. Rezultati analize so pokazali, da OIN kot motivacijsko sredstvo za udeležence prikazuje začrtano pot izobraževanja in omogoča sprotno evalvacijo. To motivira tudi določen delež izvajalcev, saj se $\mathrm{s}$ tem potrjuje njihova ustrezna priprava OIN. Ti izvajalci oziroma organizatorji izobraževanja hkrati ocenjujejo, da priprava in izvajanje OIN pripomoreta $\mathrm{k}$ večji kakovosti izobraževalnega procesa, kar je lahko pomembno motivacijsko sredstvo.

Po mnenju nekaterih organizatorjev del udeležencev izobraževanja OIN dojema kot le še en papir, ki je namenjen šoli in ne njim, in v teh primerih ga gotovo ne doživljajo kot motivacijo pri svojem izobraževanju. Deloma pa je to lahko posledica nerazumevanja ali negativnega pristopa organizatorja $\mathrm{k}$ OIN.

Podatki ankete so pokazali, da kar za polovico organizatorjev izobraževanja priprava in izvajanje OIN nista motivacijsko sredstvo, temveč prej težava. Tudi analiza intervjujev kaže, da večine odraslih udeležencev izobraževanja OIN posebno ne motivira. Ugotavljamo, da so odgovori udeležencev izobraževanja, ki pozitivno vrednotijo svoj OIN in njegov učinek, povezani z načinom priprave načrta; če je posameznik vpet $\mathrm{v}$ pripravo OIN, če sam dejavno sodeluje in sproti osmišlja cilje, zapisane $\mathrm{v}$ OIN, potem to običajno uporabi kot vodnik in motivacijsko sredstvo za lasten napredek v izobraževalnem procesu. Tam, kjer je OIN pripravljen bolj zato, da se zadosti predpisanim zahtevam, OIN ne motivira in ne vpliva na potek izobraževanja ter uspešnost udeležencev.

Kot navajajo strokovnjaki, se udeleženci izobraževanja pri uresničevanju OIN srečujejo z različnimi ovirami, ki jih lahko razdelimo $\mathrm{v}$ situacijske, sistemske in dispozicijske; $\mathrm{z}$ njimi pa se glede na interakcijo $v$ izobraževalnem procesu srečuje tudi organizator izobraževanja. Analiza intervjujev kaže, da se odrasli udeleženci izobraževanja znajdejo pred mnogimi ovirami v procesu izobraževanja. Največkrat naštevajo situacijske ovire 
(pomanjkanje časa, družinske obveznosti, previsoki stroški izobraževanja in oddaljenost kraja izobraževanja), nekoliko manj dispozicijske (težave s koncentracijo, lenoba, starost), nekaj pa jih omenja tudi institucionalne ovire (neustrezen čas izobraževanja, izobraževanje ni organizirano v skladu z OIN, pomanjkljivo sestavljen OIN). Večino teh težav poskušajo reševati sami ali s pomočjo družine.

Po mnenju organizatorjev izobraževanja se težave pri uresničevanju OIN kažejo v pomanjkljivi motivaciji udeležencev, ki je posledica številnih osebnih ovir, kot so družinske obveznosti, pomanjkanje časa, služba, bolezen, materinstvo, oddaljenost ipd., kar jih odvrača od doslednega sledenja svojemu izobraževalnemu načrtu.

Med 17 anketiranimi izobraževalnimi ustanovami težave pri pripravi in izvedbi OIN zaznavajo na devetih (Tabela 3 ).

Tabela 3:Kakšne težave imate pri izvajanju osebnega izobraževalnega načrta?
Iz Tabele 3 je razvidno, da ima največ anketiranih težave zaradi pomanjkanja časa zaposlenih in prevelikega števila odraslih kandidatov za poklicno in strokovno izobraževanje. Priprava OIN običajno poteka skupaj z vpisom, kar pomeni, da se na ustanovi naenkrat pojavi ogromno število novih kandidatov, in v takšnih razmerah sami organizatorji (praviloma $\mathrm{v}$ eni osebi) ne utegnejo nameniti dovolj pozornosti vsakemu posamezniku, zmanjka jim časa za kakovostno individualno obravnavo. Zaradi velikega števila vpisanih organizatorji ne morejo sami poskrbeti, da bodo vsi udeleženci imeli kakovostno narejen OIN.

Kot pogoste težave pri uresničevanju OIN organizatorji izobraževanja navajajo še pomanjkanje strokovne usposobljenosti preostalega zaposlenega osebja, premalo praktičnih izkušenj na tem področju, premalo ustreznega kadra, preveliko zapletenost izpeljave celotnega postopka, preveč administrativnega oz. birokratskega dela, številčnost in raznovrstnost programov itd.

\begin{tabular}{|l|c|c|c|c|c|c|c|}
\cline { 2 - 7 } \multicolumn{1}{l|}{} & $\begin{array}{c}\text { Sploh se ne } \\
\text { strinjam }\end{array}$ & $\begin{array}{c}\text { Se ne strin- } \\
\text { jam }\end{array}$ & Niti niti & Se strinjam & $\begin{array}{c}\text { Povsem se } \\
\text { strinjam }\end{array}$ & Skupai & Povprečje \\
\hline $\begin{array}{l}\text { Pomanjkanje strokov- } \\
\text { ne usposoblienosti na } \\
\text { tem področju }\end{array}$ & $6(37,5 \%)$ & $7(43,8 \%)$ & $3(18,8 \%)$ & $0(0,0 \%)$ & $0(0,0 \%)$ & $16(100,0 \%)$ & 1,81 \\
\hline $\begin{array}{l}\text { Pomanjkanje prak- } \\
\text { tičnih izkušeni }\end{array}$ & $6(37,5 \%)$ & $5(31,3 \%)$ & $4(25,0 \%)$ & $1(6,3 \%)$ & $0(0,0 \%)$ & $16(100,0 \%)$ & 2,00 \\
\hline $\begin{array}{l}\text { Pomanjkanje časa } \\
\text { Peliko število udele- } \\
\text { žencev }\end{array}$ & $0(0,0 \%)$ & $0(0,0 \%)$ & $0(0,0 \%)$ & $4(25,0 \%)$ & $12(75,0 \%)$ & $16(100,0 \%)$ & 4,75 \\
\hline $\begin{array}{l}\text { Majhno število zapos- } \\
\text { lenih na področju IO v } \\
\text { naši organizaciji }\end{array}$ & $0(0,0 \%)$ & $3(18,8 \%)$ & $3(18,8 \%)$ & $3(18,8 \%)$ & $7(43,8 \%)$ & $16(100,0 \%)$ & 3,88 \\
\hline
\end{tabular}


Veliko anketiranih je menilo, da je težava v administraciji oz. birokraciji, saj se OIN pripravlja zgolj zato, ker ga je treba imeti, če drugače ne, pa zaradi inšpekcije. Menijo tudi, da je OIN težko oblikovati, saj se nekateri udeleženci vpišejo samo zaradi statusa. Prepričani so, da je udeleženca treba res zelo dobro poznati, da bi zanj lahko pripravili kakovosten izobraževalni načrt. Prav tako je po mnenju organizatorjev izobraževanja na njihovih ustanovah zaposlenih premalo ljudi, ki bi dobro poznali vsebino Navodil o prilagajanju izrednega poklicnega in strokovnega izobraževanja.

Kot opozarjajo strokovnjaki, je le ustrezno usposobljen strokovni delavec oz. svetovalec, ki pozna temeljne značilnosti učenja odraslih in njihove posebnosti pri učenju, ki obvlada spretnosti svetovalnega dela in postopke za izdelavo različnih OIN, njihovo spremljanje in evalvacijo, možnosti za izpeljavo izobraževanja v različnih organizacijskih oblikah itn., lahko v vsestransko pomoč udeležencu pri pripravi in izvedbi njegovega OIN. Strokovna usposobljenost organizatorja izobraževanja je zelo pomembna, saj je ta nekakšen svetovalec udeležencu. Pomaga mu pri načrtovanju ciljev, prav tako pa mu mora biti tudi v oporo med samim doseganjem ciljev. Strokovna usposobljenost se vidi predvsem takrat, kadar udeležencu ne gre vse po načrtih in mu je treba pomagati in spremeniti cilje.

Dobra polovica organizatorjev izobraževanja v naši anketi meni, da so ustrezno strokovno podkovani za pripravo in spremljanje izvedbe OIN udeležencev. Za razmeroma velik delež tistih, ki se do tega vprašanja niso opredelili, pa predpostavljamo, da imajo pomanjkljiva znanja in informacije o pomenu in uporabnosti OIN in bi potrebovali dodatno izobraževanje in usposabljanje na tem področju.

OIN bi bil veliko bolj motivacijsko sestavljen, če bi organizatorji izobraževanja imeli dovolj časa, da bi se lahko posvetili vsakemu udeležencu posebej in z njim naredili kakovosten načrt. Tako bi z udeležencem lahko oblikovali načrt, kako do cilja s čim več motivacije. Udeleženec bi bil veliko bolj motiviran za izobraževanje, če bi videl dejansko uporabnost svojega izobraževalnega načrta.

Po mnenju organizatorjev izobraževanja bi OIN lahko postal motivacijsko sredstvo, če bi na njihovih izobraževalnih ustanovah povečali število zaposlenega osebja ter ga ustrezno strokovno usposobili za pripravo in spremljanje izvedbe OIN vseh udeležencev izobraževanja. Prav tako pa Le ustrezno
usposobljen
strokovni delavec
je lahko v pomoc
pri pripravi in
izvedbi OIN. bi bilo treba udeležence izobraževanja podrobno seznaniti z namenom in uporabnostjo OIN. Morda bi tako zmanjšali delež tistih udeležencev, ki v OIN ne vidijo posebnega smisla. Bolj redno spremljanje OIN bi lahko bila dodatna spodbuda za udeležence. Vendar je pri tem treba upoštevati, da samo dobra priprava OIN ni zadosten pogoj za uspešno motivacijo. Posamezni komentarji v vprašalniku nakazujejo, da bi večja povezanost strokovnih ustanov s področja izobraževanja odraslih, nova sistemizacija delovnih mest, usposabljanje kadrov, zagotavljanje več sredstev in zmanjšanje administrativnih del verjetno prav tako pripomogli, da bi OIN postal ustrezno motivacijsko sredstvo.

Pri udeležencih in tudi izvajalcih izobraževanja bi moralo priti do miselnega premika glede tega, da je namen OIN pomoč udeležencu, ne pa formalistična papirologija. Pripravljen mora biti na podlagi udeleženčevih interesov, potreb in zmožnosti. Strokovno podkovan in ustrezno usposobljen strokovni delavec, ki dobro pozna udeleženca, je lahko pri tem v veliko pomoč in motivacijo. Po mnenju anketiranih bo OIN 
postal ustrezno motivacijsko sredstvo, če ga bo udeleženec izobraževanja sprejel za svojega. Šele takrat bosta strokovni delavec in udeleženec skupaj spremljala uresničevanje dogovorov in skupaj evalvirala rezultate.

Poleg naštetega pa bi bilo treba spremeniti tudi organizacijo in izvedbo izobraževalnega procesa (manjšs število udeležencev, večje število učiteljev in organizatorjev izobraževanja odraslih idr.), kar bi vključevalo tudi spremenjeno vlogo učiteljev $\mathrm{v}$ učnem procesu, uporabo drugačnih metod poučevanja, drugačen način spremljanja učnih dosežkov, uvajati bi bilo treba različne podporne dejavnosti (andragoško svetovalno delo, skupinska in individualna učna pomoč ipd.), skratka, na različne načine poskrbeti za to, da OIN ne bi bil le dodatno breme za organizatorje izobraževanja in nekakšen papir za udeležence.

\section{ZAKLJUČEK S PREDLOGI}

Da bi OIN dejansko postal motivacijsko sredstvo, bi bilo treba upoštevati naslednje predloge, ki so jih dali organizatorji izobraževanja odraslih in odrasli udeleženci izrednega poklicnega in strokovnega izobraževanja, med katerimi navajamo najbolj pogoste:

- bolje seznanjati vse sodelujočo z vlogo in pomenom OIN;

- bolj povezati strokovne ustanove $\mathrm{s}$ področja izobraževanja odraslih;

- oblikovati enoten obrazec za pripravo OIN;

- $\quad$ standardizirati postopek priprave OIN;

- na novo sistemizirati delovna mesta;

- usposobiti dodatne kadre;

- vključiti učitelje $\mathrm{v}$ pripravo, izvedbo in doseganje ciljev OIN;

- $\quad$ zagotoviti več sredstev;

- zmanjšati birokracijo;

- uvesti možnost, da se OIN pripravi samo za udeležence, ki ga dejansko potrebujejo;
- $\quad$ bolj upoštevati želje, potrebe, pričakovanja in zmožnosti udeležencev;

- OIN prilagoditi posamezniku;

- zagotoviti obvezno sodelovanje udeležencev pri pripravi njihovega OIN;

- redno spremljati in vrednotiti uresničevanje OIN;

- $\quad$ pri priznavanju predhodnih znanj upoštevati tudi neformalno pridobljena znanja;

- zagotoviti, da vsak udeleženec izobraževanja dobi kopijo svojega osebnega izobraževalnega načrta;

- oblikovati OIN, ki naj vključuje priznavanje predhodno pridobljenega znanja, cilje, vsebine in časovni potek izobraževanja ter načine preverjanja znanja.

V zaključku lahko ugotovimo, da ima zasnova OIN v izobraževanju odraslih po eni strani izvore $\mathrm{v}$ psiholoških teorijah motivacije, po drugi strani pa tudi v samih andragoških načelih, ki v ospredje postavljajo avtonomnost, sodelovanje in aktivno vlogo odraslega pri svojem izobraževanju. Prav tako ugotavljamo, da je OIN lahko uporabno motivacijsko sredstvo tako za udeležence kot za organizatorje izobraževanja in učitelje pri načrtovanju izobraževalnih aktivnosti in doseganju zastavljenih ciljev, vendar pa v sedanji izobraževalni praksi to motivacijsko sredstvo še ni dovolj izkoriščeno. Opažamo namreč, da se OIN v premajhnem deležu uporablja kot motivacijsko sredstvo in da tu obstajajo še neizkoriščene rezerve tako za udeležence kot organizatorje izobraževanja. Priprava OIN je ena od oblik pomoči, s katero izobraževalci na različne načine spodbudijo in podprejo učenje posameznikov, npr. pri posredovanju ustreznih informacij in njihovem presojanju, pri zbujanju ali ohranjanju motivacije za učenje ter pri vrednotenju napredovanja posameznika $\mathrm{v}$ skladu z njegovim izobraževalnim načrtom. Toda glede na rezultate naše raziskave bo na tem področju potrebnega še veliko seznanjanja 
in angažiranosti tako izvajalcev kot odraslih udeležencev izobraževanja, po drugi strani pa tudi več podpore $\mathrm{v}$ smislu drugačnega načrtovanja izobraževalne politike in možnosti za poklicno in strokovno izobraževanje odraslih.

\section{LITERATURA IN VIRI}

Anderson, G., Boud, D., Sampson, J. (1996). Learning Contracts: A practicalguide. London: KoganPage.

Bandura, A. (1997). Self-efficacy: The exercise of control. New York: Freeman.

Brookfield, S. (1985). Self-directed learning: A critical review of research. New Directions for Adultand Continuing Education, 25: 5-16.

Brockett, R. G., Hiemstra, R. (1991). Self-direction in adult learning: Perspectives on theory, research, and practice. New York: Routledge.

Candy, P. C. (1991). Self-direction for Lifelong Learning: A comprehensive guide to theory and practice. San Francisco: Jossey-Bass.

Deci, E. L., Ryan, R. M. (1985). Intrinsic motivation and self-determination in human behavior. New York: Plenum Press.

Deci, E. L., Ryan, R. M. (2012). »Self-determination theory«. V: Van Lange, P. A. M., Kruglanski, A. W., Higgins, E. T. (ur.), Handbook of theories of social psychology (Vol. 1). ThousandOaks.

Glaser, B. G., Strauss, A. (1967). The discovery ofgrounded theory: Strategies for qualitative research. Chicago: Aldine Publishing Co.

Houle, C. O. (1993). The inquiring mind. Norman: Oklahoma Research Center for Continuing Professional and Higher Education.

Justinek, A., in drugi (2010). Osebni izobraževalni načrt. Ljubljana: Center za poklicno izobraževanje.

Klemenčič, S. (2004). »Zakaj načrtovati izobraževanje in učenje?« V: M. Velikonja (ur.): Osebni izobraževalni načrt. Ljubljana.

Knowles, M. S. (1975). Self-directed learning. A guide for learners and teachers. Englewood Cliffs.

Knowles, M. S. (1991). Using learning contracts. San Francisco: Jossey-Bass.
Mesec, B. (1998). Uvod v kvalitativno raziskovanje v socialnem delu. Ljubljana: Visoka šola za socialno delo.

Možina, T. (2004). »Vrste osebnih izobraževalnih načrtov«. V: Velikonja M. (ur.), Osebni izobraževalni načrt. Ljubljana.

Navodila o prilagajanju izrednega poklicnega in strokovnega izobraževanja. (2008). Uradni list RS, št. 8/2008. Dostopno na: http://zakonodaja. gov.si/rpsi/r04/predpis_NAVO914.html.

O`Donnell, J. M., in Caffarella, R. S. (1991). »Learning contracts «. V: M. W. Galbraith (ur.), Adult learning methods: A guide for effective instruction. Malabar: Krieger.

Pintrich, P. R. (1989). The dynamic interplay of student motivation and cognition in the college classroom. V: Maehr,M. L., Pintrich,P. R. (ed.), Advances in motivation and achievement: A research annual, Vol. 6. Greenwich.

Pintrich, P. R., Garcia, T. (1991). »Student goal orientation and self-regulation in the college classroom«. V: Maehr,M. L.,. Pintrich,P. R.(ur.), Advances in motivation and achievement: A research annual, Vol. 7. Greenwich.

Strauss, A., Corbin, J. (1990). Basic of qualitative research: Grounded theory procedures and techniques. Newbury Park: Sage Publications.

Tough, A. (1979). The adult's learning projects. Toronto: Ontario Institute for Studies in Education.

Zakon o poklicnem in strokovnem izobraževanju ZPSI-1 (2006). Uradni list RS, št. 79/2006.

Dostopno na: http://www.uradni-list.si/1/objava. jsp?urlid=200679\&stevilka=3449 (20. 2. 2011).

Zimmerman, B. J., Martinez-Pons, M. (1990). »Student differences in self-regulated learning: Relating grade, sex, and giftedness to self-efficacy and strategy use«. Journal of Educational Psychology, 1: 51-59.

Zimmerman, B. J. (2002). »Becoming a self-regulated learner: An overview «. Theory Into Practice, 41(2): 64-70. 
1. Raziskava o motivaciji odraslih za izobraževanje se je izvajala v letih 2011-2012 in je del evalvacijske študije »Motivacijski dejavniki v izobraževanju mladine in odraslih«, katere nosilec je bil Pedagoški inštitut.

2. Izbrali smo prevod »utemeljena teorija«, ki ga uporablja Blaž Mesec; drugi avtorji so termin Grounded Theory prevajali še kot pritlehna teorija (V. Flaker), bazična teorija (B. Dekleva) ipd. 